\title{
Complete Sequencing vs. Reductionism in the Human Genome Project
}

\author{
Masayuki ОвауASHI
}

\section{1) Introduction}

The Human Genome Project (hereafter, the HGP) is now under way as an international scientific research project, with the main purpose of gene mapping and base sequencing of the human genome. ${ }^{(1)}$ The HGP is regarded as a result of the physico-chemical approach to biological phenomena in modern biology. ${ }^{(2)}$ However, not only social and ethical questions but also methodological ones have been raised concerning the HGP. ${ }^{(3)}$ For example, one of the methodological questions is whether or not the complete sequencing which reveals the sequence of bases of the entire human DNA can reduce the biological phenomena to the sequence of bases. ${ }^{(4)}$

In this paper, I will discuss some critical arguments concerning the reductionistic methodology in the complete sequencing of the human genome, and show the biological meaning of complete sequencing in the HGP.

\section{2) The Development of Sequencing and the Origins of the HGP}

I will review the technological development of sequencing of DNA before discussing the critical arguments about complete sequencing in the HGP.

(a) The Development of Sequencing

In the 1960's, the term "sequence" meant mainly the sequence of amino acids of a protein..$^{(5)}$ At that time, we could infer the sequence of the bases of DNA of the gene from the sequence of the amino acids of the protein which is the product of the gene. At that time, we had no method to elucidate the sequence of the bases of DNA of the gene physico-chemically.

However, in the 1970's, two biological technologies concerning sequencing of the bases of DNA were developed. One of them is the recombinant DNA technology which can produce many of the same DNA fragments of a gene by cloning. The other is the technology of sequencing the bases of DNA. This technology has two methods: the Maxam-Gilbert method presented in 1977(6), and the Dideoxy method used by Sanger to determine the sequence of all bases of $\phi X 174$ genome in 1978. ${ }^{(7)}$ These methods showed that DNA can be sequenced by "a chemical prosedure."(8)

School of Medicine, University of Occupational and Environmental Health, Kitakyushu 807, Japan 
This phrase "a chemical procedure" has a crucial meaning in biology. Up until that time, in order to determine the DNA sequence of a gene, scientists had to search the locus of the gene on the chromosome using genetic procedures, and then using the genetic map, they clarified that the protein is the product of the gene, and determined the sequencing of amino acids to sequence the nucleotides of DNA of the gene. After these two methods of sequencing were developed, researchers were able to determine the sequence of the bases of DNA as chemical substances without biological and genetic procedures. However, it was not only these two sequencing methods that led scientists to elucidate the complete sequence of the entire human DNA. At that time, the method of mapping human genes was developing. Many genes that cause diseases were isolated within the human chromosomes. ${ }^{(9)}$ Also, the methodology of mapping human genes was developed with RFLP(Restriction Fragment Length Polymorphism). ${ }^{(10)}$ In 1980, Botstein and his colleagues raised the possibility of using RFLPs to make a genetic map of a human being. In 1985, the PCR (Polymerase Chain Reaction) method was discovered.(1) This method can produce many clones of a particular fragment of DNA. In 1987, Yac (Yeast Artificial Chromosome) was developed. Yac produces clones of $2000 \mathrm{kbps}$ of DNA and by it the positional cloning method was established. These methods stimulated the idea of elucidating the entire sequence of human genome. ${ }^{(12)}$

(b) The Origins of the HGP

When the U.S. Department of Energy proposed the research plan of HGP in 1985, the first purpose of the research was the sequencing of the entire human DNA. ${ }^{(13)}$ However, at that time, the mapping and sequencing of all the human genes was criticized for various reasons, for example, funding and scientific values. ${ }^{(14)}$ When, in the United States, the HGP was started formally with the cooperation of the Department of Energy and National Institutes of Health in $1990^{(15)}$, the complete sequencing was taken as merely one of several purposes of the HGP.(16) Such a change of status regarding complete sequencing in the HGP was a sign of the importance of the critical arguments concerning complete sequencing. ${ }^{(17)}$ And these arguments continued to be raised after the HGP had begun.

\section{3) Critical Arguments against Complete Sequencing in the HGP}

At the beginning of HGP, the idea of the sequencing of human DNA as the first aim of HGP was criticized for various reasons. The critical arguments against complete sequencing had two versions concerning its scientific values. One was that because human genes are $5 \%$ of the entire human DNA, sequencing of $95 \%$ of human DNA is meaningless. ${ }^{(18)}$ Therefore, most of the complete sequencing is a vain effort. ${ }^{(19)}$ The other was that it is difficult to understand functions from sequences of unknown function. ${ }^{(20)}$ For example, the critical arguments are directed to the 
following :(21)

- The protein-folding problem: Is the 3 dimension structure of a protein explained by the sequence of the bases of the gene?

- The epigenic control on DNA transcription: Is there any epigenic control on DNA transcription?

- The problems of developmental and regenerative phenomena: Is the phenomena of development and regeneration explained only by the base sequence of the gene?

- Organizational explanation of complex systems such as the immune and neuronal networks : Can we have a organizational explanation of the complex systems such as the immune and neuronal networks?

- Programmed cell death: Is the cell death programmed on the base sequence of a gene?

- Activation of the proto-oncogene function: Is an activation of protooncogene function explained only by the base sequence of a gene?

- Genetic polymorphism: Is the genetic polymorphism explained only by the certain sequence of the base of the gene? etc.

When discussing these problems, sequencing is referred to as "blind sequencing,"(22) that is to say,

At its worst, research has been driven by investigative programs not sufficiently cognizant of any broader biological contexts. The blind sequencing of DNA is just such a case. Thus has come about the Human Genome Project. ${ }^{(23)}$

However, every sequencing was not labeled "blind sequencing." Sequencing in the following two appoaches is thought to link function to sequence of the gene, as follows :

Another concern is that the real goal is establishing links between genes and the functions that they influence and not sequencing as an end in itself ; and the question is how best to establish these links. The familiar, function-based (or top-down) approach, [as noted above,] proceeds in the direction from known function to localizing the gene. ${ }^{(24)}$

And,

The alternative, sequence-based (or bottom-up) approach would proceed in the opposite direction: after systematic, blind sequencing has revealed a region with features suggesting function as a gene, the next step is to determine in what stage in development the product of that gene does its job. ${ }^{(25)}$

That is to say, one of the two kinds of sequencing is "the sequencing in the function-based (or top-down) approach" (hereafter "top-down sequencing"). Another is "the sequencing in the sequence-based (or bottom-up) approach" (here- 
after "bottom-up sequencing"). The sequencing in the latter approach, namely bottom-up sequencing, means "blind sequencing."(26) Then, what are the top-down and the bottom-up approaches? In following paragraphs, I will try to make the meaning of these approaches clear.

\section{4) Two Approaches to the Link between Function and Sequence of DNA}

(a) The Top-down approach

The top-down approach was described by J.D. Watson, one of the proponents of the HGP, as follows :

"[T]op-down" approach, in which a genome or chromosome is gradually subdivided into regions of smaller and smaller size, while determining the order of regions at each step along the way. ${ }^{(27)}$

Also,

"[T]op-down" approaches, i.e., those methods which do not require any conventional, random cloning in foreign vector/host systems, but which are based on the isolation of well ordered, contiguous $\lambda$-sized DNA fragments directly from the cell genome followed by their processive and well ordered sequencing by primer walking, without the necessity for random subcloning in M13 phage vector. [Italic by the original author] ${ }^{(28)}$

In fine, the top-down approach seeks sequences of the gene resulting from the mapping of the gene, the function of which is already known. That is to say, this approach goes from the function of the gene to its sequence.

(b) The bottom-up approach

The bottom-up approach is described as follows:

The so-called "bottom-up" approach, in which long-range maps are assembled by identifying overlapping regions in random generated phage or cosmid clones, has worked rather successfully in generating partial maps for the genomes of organisms such as E. coli, Saccharomyces cerevisiae, and C. elegans. ${ }^{(29)}$

Moreover,

In this [bottom-up] approach, the fragments for sequencing are chosen and prepared at random, and the sequencing is also random. With the help of computers, the sequense data thus obtained permit one to find sequences overlaps, to build contigs, and eventually to assemble the entire sequence, when all the necessary sequences become available. ${ }^{(30)}$

In short, the bottom-up approach elucidates the sequence of DNA without knowing its function. That is to say, this approach goes from the sequence of the gene to its function. 


\section{5) Sequencing vs. Reductionism}

As mentioned above, complete sequencing is criticized because, even if we know the sequence of the gene, we can not explain the function of the gene by its sequence. In other words, we can not reduce the function of the gene to its sequence. Then, is the aim of sequencing to reduce the function of the gene to its sequence? Is the sequencing brought about by such a reductionism?

In this paper, three types of "reductionism" are considered, as follows :(31)

(1) Ontological reductionism

This reductionism is based on the idea that "there is nothing at the macrolevel which is not made up of parts existing at the micro-(or any specified) level."(32) In this sentence, "the microlevel" is thought to mean the molecular level. Therefore, in genetics, "the overall physical body-animal, plant, or microorganism-is no more than the parts,"(33) that is to say, molecules.

(2) Methodological reductionism

This reductionism characterizes the methodology of modern science, that is to say, "the triumphs of science come through the revealing and understanding of ever-smaller entities of nature." ${ }^{(34)}$ According to the traditions of modern science, the HGP is "the attempt to reveal the whole of the human genetic story at the molecular level."'(35)

(3) Epistemological reductionism

Strictly speaking, "the 'reduction' is said to occur when one theory, or branch of theory, is taken into or absorbed by another theory, or branch of theory."(36) Ultimately, the aim of the HGP is to reduce the functions of the genes, which are explained by genetics, to the sequences of DNA, which are revealed by physical and chemical procedures: that is to say, physics and chemistry. Such a reductionism is called epistemological reductionism.

The following is a discussion on the relation between sequencing and the three types of reductionism mentioned above. ${ }^{(37)}$

(a) Bottom-up Sequencing is not Methodological and Epistemological Reductionism

In the case of bottom-up sequencing, we have to present the functions to the sequences, because sequencing does not depend on the functions of DNA. Before we reduce the function of a particular gene to the sequence of DNA of that gene, we have to recognize its function. In this sense, bottom-up sequencing fundamentally depends on ontological reductionism, but it differs from methodological and epistemological reductionism, because, in this case, we do not know the function of the gene, which is made of molecules, and which we have to reduce to the sequence of the gene. If we want to reduce the function of the gene to its sequence, we have to describe the function of the gene and its sequence separately. Therefore, the critical 
arguments concerning the reductionism of sequencing in the HGP are misguided.

Of course, we can not deny the possibility of inferring the function of the gene from its sequence, using physical and chemical considerations. Some biologists have suggested that informatics, that infer the functions of the sequences of human genome stored in the database, is an important subject in the HGP. ${ }^{(38)}$ I think that it is very natural for them to have come to this conclusion.

(b) Top-down Sequencing is not Epistemological Reductionism.

Next, how about top-down sequencing? Does it belong with reductionism? The top-down sequencing depends on the mapping of human genes on chromosomes, as mentioned above. It is done by understanding the functions of the gene from the knowledge of the genetic trait. Therefore, "top-down" sequencing is functionbased, as mentioned above. ${ }^{(39)}$ In other words, top-down sequencing is to elucidate the sequence of the gene whose function is already known, and not to explain the function of the gene by its sequence. That is to say, top-down sequencing is to describe the base sequence of DNA included in the gene whose function is already known genetically. Therefore, top-down sequencing has no connection with reducing the function of the gene to its sequence. It is only a method to elucidate the sequence, that is to say, the chemical structure of the gene whose function is already known. In this sense, top-down sequencing basically depends on ontological and methodological reductionism, but it differs from epistemological reductionism.

\section{6) Conclusion}

At the present time, the complete sequencing is not a prime purpose of the HGP, but still an ultimate aim. However, its scientific significance is being criticized.

The critical arguments against sequencing are connected with two approaches to link the function and sequence of the gene: bottom-up and top-down approaches. Here, when we think that the reductionism in the critical arguments against sequencing means epistemological reductionism strictly, criticizing bottom-up sequencing as "unsuccessful reductionism"(40) is improper, because bottom-up sequencing reveals the base sequence of DNA only chemically without knowing the functions of the gene. And criticizing top-down sequencing as "reductionism" is also improper because, depending on the known function of the gene, such sequencing reveals only the sequence of the gene without reducing the function to the sequence.

To sum up, the criticism of sequencing in the HGP concerning epistemological reductionism is improper, because bottom-up sequencing is literally "blind sequencing" which reveals the meaningless sequence, and top-down sequencing depends on mapping of the genes whose functions are already known. Therefore, only topdown sequencing has a biological meaning in the HGP.

However, after we justify the biological meaning of the top-down sequencing in 
the HGP, we still have a serious problem. That is to say, the sequence which we can elucidate is included in a very narrow region of the entire human genome. We therefore have to use the knowledge contained in various fields of biology in addition to genetics in order to reveal the sequence of the gene. ${ }^{(41)}$

Finally, we have to regard the HGP as merely one means to objain a biological understanding of the human being. At the same time, it is neccesary for us to think of the biological meaning of sequencing in the HGP as a biological procedure that depends on other biological knowledge. ${ }^{(42)}$

\section{Notes}

(1) R. Cook-Deegan, The Gene Wars: Science, Politics, and the Human Genome (New York: W.W. Norton \& Company, 1994), pp. 187-230.

(2) A.I. Tauber and S. Sarkar, "The human genome progect: has blind reductionism gone to far?" Perspectives in Biology and Medicine, 35(1992), pp. 220-235.

(3) Tauber and Sarkar, op. cit., pp. 221-231.

B.D. Davis and Colleagues, "The human genome and other initiatives," Science, 249(1990), pp. 342-343.

B.D. Davis, "Sequencing the human genome: a faded goal," Bulltin of New York Academy of Medicine, 68(1992), pp. 115-125.

(4) Tauber and Sarkar, op. cit., pp. 221-228.

Davis, op. cit., p. 20.

M. Rechsteiner, "The human genome project : two points of view,"

FASEB Joumal, 4(1990), pp. 2941-2942.

(5) B. Barrell, "DNA sequencing: present limitations and prospects for the future," FASEB Journal, 5(1991), pp. 40-45.

Cook-Deegan, op. cit., pp. 13-28, 56-77.

(6) A.M. Maxam and W.Gilbert, "A new method for sequencing DNA," Proceedings of National Academy of Science, 74(1977), pp. 560-564.

(7) F. Sanger, S. Nicklen, and A.R. Coulson, "DNA sequencing with chain-terminating inhibitors," Proceedings of National Academy of Science, 74(1977), pp. 5463-5467.

F. Sanger and A.R. Coulson, "The use of thin achrylamide gels for DNA sequencing," FASEB Letters, 87(1978), pp. 107-110.

F. Sanger, et al., "The nucleotide sequence of bacteriophage $\phi \mathrm{X} 174$," Journal of Molecular Biology, 125(1978), pp. 225-246.

(8) Maxam and Gilbert, op. cit., p. 560.

(9) V.A. McKusick, "Current trends in mapping human genes," FASEB Journal, 5(1991), pp. 12-20.

(10) D. Botstein, R.L. White, M. Skolnick, and R.W. Davis, "Construction of a genetic linkage map in man using restriction fragment length polymorphisms," American Journal of Human Genetics, 32(1980), pp. 314-331.

(11) Cook-Deegan, op. cit., p. 72.

(12) R. Dulbecco, "A turning point in cancer research: sequencing the human genome," Science, 231(1986), pp. 1055-1056.

B. Barrell, op. cit., pp. 40-45.

D.E. Koshland, Jr., "Sequencing and consequences of the human genome," Science, 246(1989), p. 189. 
M. Pearson and D. Söll, "The human genome project: a paradigm for information management in the life sciences," FASEB Journal, 5(1991), pp. 35-39.

L.W. Engel, "The human genome project history, goal, and progress to date," Archives of Pathology and Laboratory Medicine, 117(1993), pp. 459-465.

C. Ezzell, "Another report smiles on human genome sequencing project," Nature, 332 (1988), p. 769.

E.D. Green and R. H. Waterston, "The humen genome project prospects and implications for clinical medicine," JAMA, 266(1991), pp. 1966-1975.

M.V. Olson, "The human genome project," Proceedings of National Academy of Science, 90(1993), pp. 4338-4344.

(13) Davis, op. cit., pp. 116-117.

J.D. Watson, "The human genome project: past, present, and future," Science, 248(1990), pp. 44-49.

J.D. Watson and R.M. Cook-Deegan, "Origins of the human genome project," FASEB Journal, 5(1991), pp. 8-11.

(14) Davis, op. cit., pp. 116-117.

(15) Watson, op. cit., pp. 46-47.

C.R. Cantor, "Orchestrating the human genome project," Science, 248(1990), pp. 49-51.

(16) Watson, op. cit., p.47.

Pearson and Söll, op. cit., pp. 35-39.

Davis, op. cit., p. 117.

E.P. Hoffman, "The evolving genome project: current and future impact," Americal Joumal of Human Genetics, 54(1994), pp. 129-136.

E. Jordan, "The human genome project: where did it come from, where is it going ?" American Journal of Human Genetics, 51(1992), pp. 1-6.

(17) Davis and Collegues, op. cit., p. 343.

(18) Davis, op. cit., p. 120.

R.A. Weinberg, "There are two large questions," FASEB Journal, 5(1991), p. 78.

(19) Tauber and Sarkar, op. cit., p. 224.

Davis, op. cit., p. 120.

J. Palca, "The human genome project : life after Watson," Science, 256(1992), pp. 956958.

(20) Tauber and Sarkar, op. cit., p. 231.

Davis, op. cit., p. 121.

(21) Tauber and Sarkar, op. cit., pp. 221-228.

(22) Ibid., p. 231.

Davis and Collegues, op. cit., p. 343.

Davis, op. cit., p. 121.

(23) Tauber and Sarkar, op. cit., p. 231.

(24) Davis, op. cit., pp. 120-121.

(25) Ibid., p. 121.

(26) Tauber and Sarkar, op. cit., p. 231.

Davis, op. cit., p. 121.

(27) Watson, op. cit., p. 47.

(28) W. Szybalski, "From the double-helix to novel approaches to the sequencing of large genomes," Gene, 135(1993), p. 282.

(29) Watson, op. cit., p. 47.

(30) Szybalski, op. cit., p. 281.

(31) M. Ruse, "Knowledge in human genetics: some epistemologacal questions," in R.F. Weir, S.C. Lawrence, and E. Fales, eds., Genes and Human Self-Knowledge : Historical 
and Philosophical Reflections on Modern Genetics (Iowa City: University of Iowa Press, 1994), pp. 34-45.

E. Fales, "The human genome project and epistemology," in R.F. Weir, S.C. Lawrence, and E. Fales, eds., Genes and Human Self-Knowledge: Historical and Philosophical Reflections on Modern Genetics (Iowa City : University of Iowa Press, 1994), pp. 53-62. E. Shuster, "Determinism and reductionism: a greater threat because of the human genome project?" in G.J. Annas and S. Elias, eds., Gene Mapping (Newtork and Oxford: Oxford University Press, 1992), pp. 115-127.

(32) Ruse, op.cit., p. 37.

(33) Ibid., p. 37.

(34) Ibid., p. 38.

(35) Ibid., p. 39.

(36) Ibid., p. 42.

(37) For the methodological discussions of the relation of sequencing to reductionism, see the following papers,

Tauber and Sarkar, op.cit.

Davis and Collegues, op. cit.

Davis, op. cit.

(38) Pearson and Söll, op. cit., pp. 35-39.

W. Gilbert, "Towards a paradigm shift in biology," Nature, 349(1991), p. 99.

(39) Davis, op. cit., p. 121

(40) Tauber and Sarkar, op. cit., pp. 231-234.

Shuster, op. cit., 123-125.

(41) Some aspects are needed to understand biological phenomena in modern biology. For example, concerning two aspects which are complementary, see the following papers, H.J. Folse, Jr., "Complementarity and the description of nature in biological science," Biology and Philosophy, 5(1990), pp. 211-224.

M. Obayashi, "Complementarity in molecular biology: explanation of the structure of DNA," The Annals of the Japan Association for Philosophy of Science, 8(1992), pp. 111-116.

M. Obayashi, "Stent's myth in the origins of molecular biology," Historia Scientiarum, 2(1992), pp. 139-150.

E.T. Juengst, "Causation and the conceptual scheme of medical knowledge," in C. Delkeskamp-Hayes and M.A.G. Cutter, eds., Science, Technology, and Art of Medicine (Dordorecht : Kluwer Academic Publishers, 1993), pp. 127-152.

P. Hoyningen-Huene, "Niels Bohr's argument for the irreducibility of biology to physics," in J. Fay and H.J. Folse, eds., Niels Bohr and Contemporary Philosophy (Dordrecht: Kluwer Academic Publishers, 1994), pp. 231-255.

(42) For example, B. Davis noted as follows:

Biology will always have to integrate multiple levels of organization; and within that framework sequences have meaning only as they are linked to other levels. (See Davis, op. cit., p. 124.) 